Acta Poetica 27 (2)

OTOÑO

2006

\title{
Halcones: el film como creación de memoria política
}

\author{
Raymundo Mier
}

2 de julio de 1971. Un episodio de represión brutal de una manifestación estudiantil, llevada a cabo por disciplinados grupos de jóvenes consagrados a la instrumentación sigilosa, anónima, clandestina de la violencia de Estado. Una matanza. El gobierno encubre la violencia con desinformación masiva, la corrupción de los medios, con mentiras sofocantes. A esto sucede la inmediata imposición general del silencio, la invención programada del olvido. Dos mil seis: treinta y cinco años después, un film recobra material inédito y testimonios. Es la reaparición de la memoria, la indignación, la vergüenza. El presente texto es tanto un homenaje al film como una reflexión sobre el papel de la memoria, el trabajo cinematográfico, las imágenes, los testimonios, en la lucha política por la democracia, todavía por venir en México.

July $2^{\text {nd }} .1971$. An episode of brutal repression of a student demonstration, carried on by disciplined groups of young men devoted to the undercover, anonymous and clandestine instrumentation of the State terrorism. A slaughter. The government covers up the violence with massive misinformation, the corruption of the media, suffocating lies. Next, the immediate imposition of general silence, the programmatic invention of oblivion. 2006: thirty five years later, a film that recovers unpublished material and testimonies. The reappearance of memory, of indignation, of shame. The following text is both and homage to the film and a reflection on the role of memory, of film work, of images, of testimonies, in the political struggle for democracy, still to come in Mexico. 

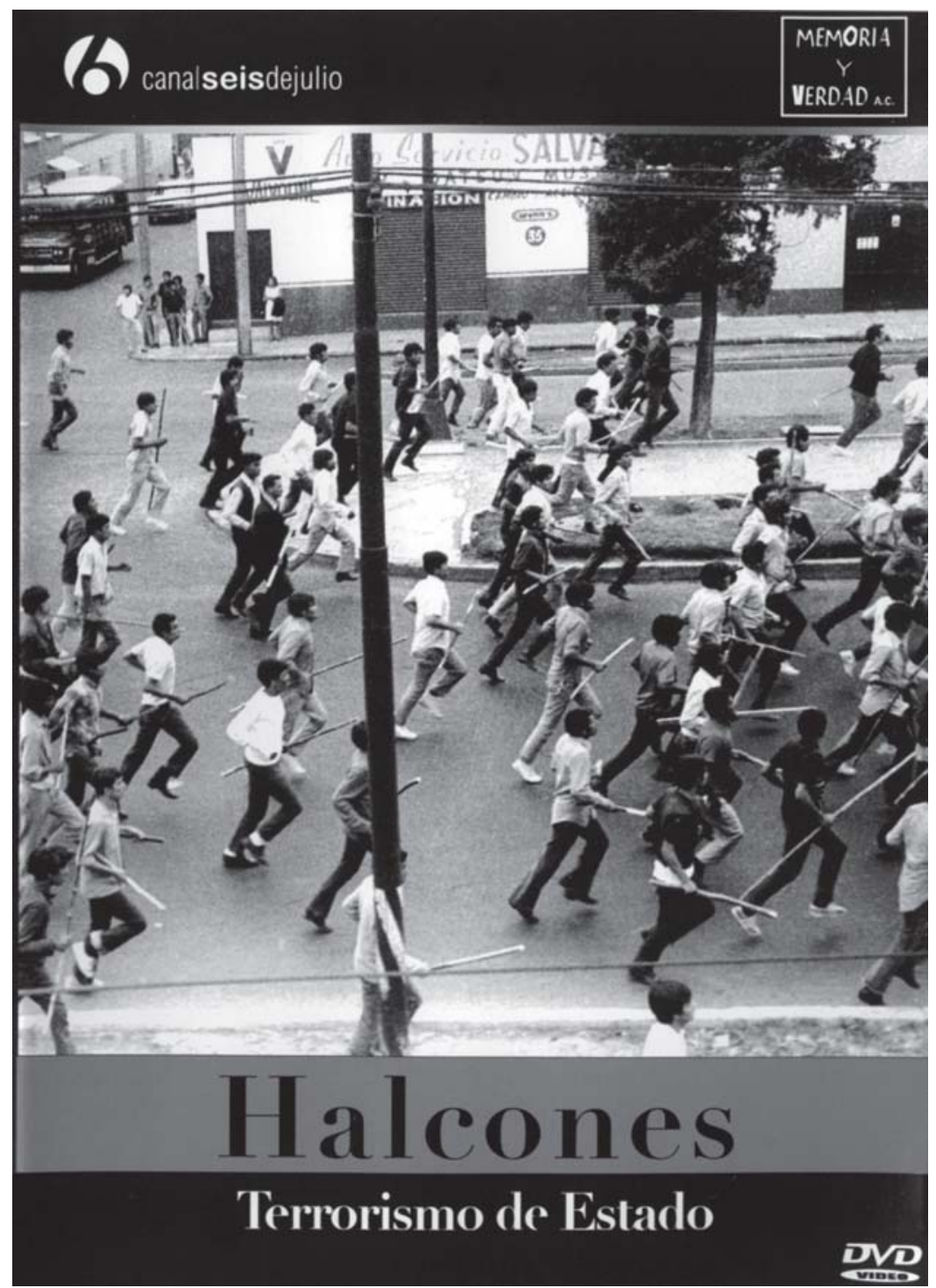

Portada del documental Halcones, terrorismo de Estado (2006) dirigido por Carlos Mendoza para Canal 6 de Julio 


\section{Halcones: el film como creación de memoria política}

\section{Configurar la memoria: la figuración analítica del terror}

Hay un silencio que acompaña a las ficciones del poder, al triunfo ilusorio pero brutal, contundente, de la barbarie. Es el silencio de la súbita visibilidad de la supremacía transitoria, que señala la mortandad de los poderes. En la opresión surgida de las confrontaciones de poder surge un lenguaje opaco, tajante, cifrado, implantado en un vasto horizonte de silencio. Las imágenes de cuerpos, de paisajes, de escenarios, se convierten en residuo monótono de voces inaudibles. La barbarie se alimenta de la vacuidad de las palabras, la construcción perseverante de su irrelevancia. Las imágenes emergen, advienen, gravitan en la memoria y en la imaginación como adherencias a relatos contingentes, jirones de evocación, reminiscencias hilvanadas en el vórtice del miedo. Acuden al desafío crucial de lo político, a la preservación de la propia integridad derivada de la preservación de la trama de vínculos. Pero el silencio del poder despliega palpablemente el riesgo avasallante de la desaparición propia o de los otros, la densidad del dolor: todo enunciado, incluso la mera descripción, arrastra 
consigo la fuerza silenciosa de la amenaza. El dominio se ratifica con el enmudecimiento. Alienta una memoria sin palabras hundida en el cuerpo, como un estigma inaprehensible pero indeleble, el repliegue sobre ese régimen melancólico de la palabra abismada en el dolor, inaudible. Una larva equívoca de la imaginación de la historia.

\section{Halcones. Terrorismo de Estado ${ }^{1}$}

Han pasado más de treinta años de esas imágenes, pero es una memoria viva. Las imágenes de la masacre irrumpen como si surgieran de una tierra intolerable, tienen una vigencia insólita. Prefiguran la impregnación de la violencia y la crueldad en el dominio de lo social. Son la señal de la reiteración de lo abyecto, de la bajeza que retorna, de las figuras indelebles del cinismo y la disolución del vínculo ético. Marcan el tiempo y la identidad en el momento en que se miran: esa violencia es lo inmediato, lo inminente y traza las vertientes ineludibles de la intimidad.

El cine político es una tentativa asediada por la imposibilidad. Es dar sustento narrativo a la exigencia de revertir el destino habitual de las imágenes. Es la imaginación que se alimenta de una mirada que advendrá, arrancada del pasado. Es el ejercicio de creación de vínculos éticos a través de la comunidad de lo mirado, en una intemperie de efigies desplegadas en el escenario espectacular, especular, de la modernidad. Pero

\footnotetext{
${ }^{1}$ Documental sobre la masacre del 10 de junio de 1971 en México durante el gobierno de Luis Echeverría. Dirección: Carlos Mendoza; Producción: Jesús Martín del Campo y Nancy Ventura; Comentario: Carlos Montemayor. Fotografía: Mario Viveros; Investigación: Carlos Mendoza, Jesús Martín del Campo, Paola Amaro, Leyda Martínez, Nancy Ventura, Gabriela Ávila, Edmundo Martín del Campo; Música: Gus Reyes; y Testimonios: Iván Trujillo, Francisco Ohem, Nahum Calleros, Ángel Martínez, Enrique Condés Lara, Alfredo Sánchez Ariza; Archivos fotográficos: Paco Ignacio Taibo, Lenin Salgado, Alfredo Sánchez Ariza. Canalseisdejulio. Memoria y Verdad A.C.
} 
el cine político no puede ser, irremediablemente, sino la evidencia visible de la mecánica incalificable del asesinato programado como recurso de la quietud. La exhibición política de las imágenes no es estrictamente una rememoración, ni una exhumación pública de archivos. Es la revelación insólita de una potencia de la imagen: como invención de lo vivido, como trastocamiento de la experiencia del pasado en una perspectiva delineada por el silencio, como invención del lugar y el tiempo de una mirada imposible, situada en los márgenes de una violencia que se pretendía, como toda violencia, totalizadora. El sentido político de las imágenes no surge de la insistencia en la memoria; estos relatos engarzados no la recuperan, la construyen, la incitan, la desencadenan, la arrancan de la esfera de lo indecible. La exposición del material fílmico plantea asimismo una tarea adicional para las imágenes: alentar su propio abandono, construir la memoria más allá de lo mirado, desalentar el confinamiento de la evidencia a la gravitación de lo contemplado. El desencadenamiento de la memoria como eje del vínculo: configurar un régimen narrativo de las experiencias colectivas a partir del significado retroactivo de esas figuras patentes. El sentido de acto político de la imagen está en su negación: abandonar esas imágenes, hacer de ellas la materia de una composición retrospectiva que cancela el peso de las imágenes al recrear la invención y la ficción de la memoria como horizonte. El espacio fílmico reclama un ejercicio de la invención de la visibilidad más allá de los confinamientos de lo visible, una experiencia política que desborde la evidencia que acompaña la recreación testimonial del acontecer.

En Halcones se contempla la reminiscencia fílmica de la abyección política: composición de imágenes, palabras, testimonios de un ataque brutal, del uso de los instrumentos de la violencia de Estado contra un grupo de jóvenes y adolescentes inerme; reconocer la administración minuciosa del asesinato - represión, se le llama, con una palabra que en este caso no 
deja de acarrear resonancias impropias- La crueldad instrumentada como instrumento espectacular, como régimen fascinante de lo visible alentado como políticas públicas. La celebración cínica de estrategias clandestinas, la crueldad como instrumento de intimidación. El despliegue del ejercicio de la crueldad como estrategia de control revela una faceta oscura, aunque reveladora por su carácter paradójico, cuyo rasgo crucial revela la barbarie inherente al Estado moderno: la instauración, como régimen de gestión, de la violencia ilegítima institucionalizada, la transfiguración de lo jurídico en una figura estratégica de enceguecimiento y mutismo, y la obsolescencia de los ordenamientos institucionales a partir del recurso al exterminio como horizonte de la dinámica de poderes. La plena visibilidad de lo intolerable, la exhibición paradójica de la clandestinidad de esa violencia estatal exacerbada es una condición suplementaria de la crueldad: la exaltación de la inhumanidad radical del asesinato.

La ilegitimidad de la violencia revela una fuerza estratégica suplementaria: la exhibición de la crueldad. La contemplación o la escucha de los testimonios de la masacre pone en relieve un juego siniestro, una formación del delirio y su despliegue espectacular instaurados como instrumento político. Revela en lo político el juego insidioso de visibilidades. El aparato de Estado hace uso de ese suplemento incalificable de violencia: llevar a la exhibición paroxística una violencia intolerable, inadmisible, más allá de todas las fronteras inherentes a lo humano. Fincar el cinismo del poder en una violencia por encima de la violencia, que excede los linderos de la violencia "legítima", expropiada por el Estado al ejercicio colectivo del control político. Hacer visible una violencia cuyos sustentos y eficacia radican en la fragilidad de la visibilidad y la prescripción de olvido.

El ejercicio moderno de la inhumanidad radical, de la barbarie en los sistemas "democráticos", tiene una fisonomía 
reconocible: no es el despojo o la ausencia de racionalidad, no es el producto de una efusión instintiva, tampoco la cancelación de una disciplina y el desencadenamiento de una vocación primaria e irrestricta de aniquilamiento. Esa inhumanidad radica en la disipación de la ética o el olvido del lenguaje como régimen de la acción política. Es la exacerbación deliberada de un sistema de control de las acciones públicas, de los lenguajes; es la mutación instrumental de las ataduras del vínculo, la exacerbación de las figuras del solipsismo, orientada a la construcción atomizada de regímenes de excepción. Es la creación de una excepcionalidad construida como faceta de las formas de vida contemporánea. Una exaltación de la individualidad desplegada como horizonte, como régimen de fantasía y de deseo, edificada desde una dominación ilegítima e impune destinada a afectar las formas privadas e íntimas de la convivencia.

\section{Historias y geografías de la abyección: memoria de lo intolerable}

En América Latina esa barbarie lleva la impronta de un momento histórico definido: la agudización de la guerra fría y el macartismo — con las secuelas de degradación en el control político y la intervención abierta, transnacional, de las agencias estadounidenses de inteligencia, rectoras de la instrumentación de terrorismo global—, la irrupción perturbadora de la imaginación socialista expresada en múltiples facetas y movimientos diseminados geopolíticamente, las invocaciones de la revolución convertida en clima y en horizonte de significación para la acción política, la exacerbación de la intervención estadounidense visible en el control político latinoamericano, la sospecha y la vigilancia como una impregnación estratégica, instrumentada tecnológicamente y omnipresente en las empresas 
de gestión, en el capital financiero y en la comunicación masiva. Estrategias de violencia ilegítima incorporadas calculadamente en el aparato político - la administración del dolor, la tortura, el asesinato y la desaparición selectiva o indiferenciada, la gestión del asesinato y la muerte anónimas, el control de la visibilidad y la ficción errática de los lenguajes - , transfiguradas en narraciones convencionales, en saturación de las atmósferas de la percepción, en imaginerías dispuestas como atmósfera ineludible que acompaña la proliferación fantasmal de mercancías. La violencia del confinamiento del sujeto en esferas circunscritas que han suplido la experiencia de la creación pública. La implantación de una atmósfera omnipresente de amenaza en todos los ámbitos de la vida colectiva.

El film hace visibles escenas destinadas a poner en evidencia el cálculo de la espectacularidad incorporada a la violencia de Estado como una forma suplementaria de la amenaza. Aparecen en pantalla contingentes de ataque dispuestos en operativos militares despojados de uniformes, organizados para confundirse con ciudadanos ordinarios. El film recobra entonces una visibilidad cifrada: apunta las historias de abyección de los sujetos, recoge y hace patente las trayectorias de asesinatos y la participación en cuerpos militares clandestinos destinados a sostener el ejercicio encubierto de las masacres. Se reconoce el orden militar: quienes imparten órdenes, señalan individuos y movimientos, intercambian palabras en medio del ataque, ordenan los disparos o los ataques, fijan coordenadas, establecen patrones de ocupación, avance o retroceso: cerrar el paso a la huida, exacerbar el miedo; matar al azar para hacer patente la distribución irracional del asesinato, su voluntad de anonimato, su indiferencia; la diseminación de terrores aleatorios. Es la teatralidad de los asesinos como rasgo inherente a la barbarie amparada en el cálculo contemporáneo del dolor y la amenaza: la construcción del azar de la muerte y la tortura, la gestión del asesinato aleatorio conjugado con la 
represión selectiva. El anonimato se confunde con las listas de líderes de nombres, apellidos, datos familiares, direcciones, una doble estrategia del miedo atenazando las vidas ordinarias, implantado como estrategias del control social. El ejército encubierto, el uso militar de la cobardía mimética. Contingentes de jóvenes arrancados de la miseria, sometidos a la lógica de un Estado que les confiere la investidura de mercenarios, los inviste como sicarios impunes azuzados para la retacería de rostros y vísceras. Una abyección sin finalidad sostenida por armas disparadas sobre almas sin guerra, ni oponente, ni alternativas de sometimiento o exterminio. Guerra sin guerra: asesinato estratégico, calculado, unilateral.

El film puso a la luz la avidez de esos rostros de mercenarios reclutados en la bajeza. Vemos las imágenes de contingentes criados en barrios miserables, dotados de armas de alto poder, que emergen, coordinados, adiestrados, orientados disciplinadamente en movimientos imprevistos, acudiendo al recurso militar de la sorpresa como en una batalla que jamás habrá de ocurrir. Simulan una guerra inexistente, disparan a cuerpos transformados en objetos indiferentes, blancos sin identidad y sin respuesta, asesinatos prescritos, prefabricados, fruto de la planeación del terror como la inseminación indiferenciada, caprichosa, de la muerte impersonal, calculada. Vemos también los gestos indiferentes ante la contemplación de las heridas. Golpes a mansalva sobre rostros, desgarramiento de torsos e historias indefensas, cuerpos arrojados a la indiferencia de una muerte inexplicable, sin causa, sin sentido, incalificable; al mismo tiempo, la invención de culpabilidades.

Miramos la reconstrucción de la estrategia del asesinato: los mapas de las calles, la meticulosa planeación de los movimientos, el montaje del asedio, la demorada vigilancia, la identificación de los líderes, la construcción de la muerte anónima, la invisibilidad del asesinado, las huellas borradas, la desaparición y el encubrimiento de todo el operativo, la devolución a 
las calles de su fisonomía habitual sin otra huella que la memoria indeleble de los testigos mudos, aterrorizados. Construir en la ciudad una geología de la matanza.

Las imágenes del film ofrecen evidencias perturbadoras: los francotiradores dispuestos en azoteas y ventanas, disparando sobre un contingente inadvertido, los participantes desconcertados, aterrorizados o exaltados a medida que se escucha el tiroteo. Adivinamos la cuota potencial de crueldad en el despliegue de los contingentes armados con instrumentos orientales de ataque, las distribuciones de armas de alto poder en manos de oleadas de asesinos reclutados de las cloacas y alimentados con desechos y la promesa de la impunidad. Bitácoras de un ejército orillado a la obscenidad del terror sin riesgo, del asesinato bajo el encubrimiento de un olvido programado y prescrito. Asesinatos realizados en la promesa de la desmemoria, del vacío de relatos, sin más reminiscencias que la ignominia depurada de toda sombra de culpa.

Un segmento del ejército elegido para la inmundicia de la masacre: contingentes militares de "élite" que buscan sustraerse de toda memoria, de toda identidad, de toda historia; que han elegido una acción política velada, insostenible, asumiendo sólo la culpabilidad inerte, desdeñable, del asesinato anónimo. Miramos un ejército que asumió la servidumbre íntima de una indignidad originada en la masacre sin combate: un combate poblado de cuerpos de adolescentes y niños ensangrentados, destrozados. Generales y alcurnia militar cebados en cadáveres civiles. Es el simulacro, la farsa abyecta del terror divino, la muerte distribuida con la racionalidad del control como goce inherente al asesinato premeditado, sin objetivo, sin fundamento, sin ética. A ese juego mimético sigue entonces la sofocación de la palabra, la destrucción de las imágenes: el espectáculo reducido al residuo de las improntas de terror en la memoria; el silencio, los nombres borrados, la confusión y la mentira, el oprobio de la calumnia, la invención de efigies infamantes que se proyectan 
sobre los cadáveres; la sombra de esa muerte proyectada sobre todos los sobrevivientes como amenaza tangible.

Para la mayor parte de quienes vemos esas imágenes en Halcones, se trata del ejercicio de una memoria plenamente política surgida del vínculo inatestiguable con los muertos: rememorar y vivir lo imposible de mirar y vivir; la reminiscencia de la muerte del otro, asumir la desaparición de quienes nos conciernen como huella del enfrentamiento con la abyección, sin la atadura de apegos previos. Esta recreación viva de la desaparición programada devuelve a la narración lo que se buscó acallar sin falla, sustraer del horizonte del lenguaje y de la mirada.

El relato de Halcones asume esta tarea cardinal: recobrar en las calles de Santa María la Ribera, en las inmediaciones de la Normal, en las instalaciones del Casco de Santo Tomás, las lápidas de palabras, los monumentos de reminiscencia pura, los epitafios de imágenes fílmicas exhumadas como tumbas labradas con relatos y estampas de las fachadas de las calles. Entrelazar la serie de testimonios de los sobrevivientes sustentados por las inflexiones de la voz trémula con los impulsos entrecortados del relato. Inventar una memoria que tiene como evidencia testimonial la voz quebrada o exaltada ante las imágenes vueltas a vivir, la respiración vacilante, la mirada que se hunde en las imágenes restauradas como exhumadas de la intimidad de la memoria para quebrarse en la palabra, en el jadeo de un dolor, una fatiga y una derrota que repuntan en las inflexiones del relato.

Los episodios narrados por los testigos parecen engendrar las imágenes fílmicas, los cuadros fotográficos, los registros visuales rescatados de archivos recónditos, de oficinas, de cajones deliberadamente extraviados, sepultados durante años en bodegas marginales. La imagen asemeja así un suplemento de la voluntad testimonial: despliega y recrea lo imaginado en la palabra, hace visible lo que persiste en el silencio de lo 
narrado, pone ante los ojos la visión tácita en las voces ahogadas, la lógica intolerable de lo contemplado. Esas imágenes nos convierten en plenos sobrevivientes, sujetos de miradas que contemplan por primera vez desde puntos de vista insólitos el paisaje del asesinato. Desvivimos, con quienes los narran, la secuencia de aquellos episodios. Mil novecientos setenta y uno: rostros, peinados, lenguaje, consignas, figuras, deseos, rechazos, utopías, esperas, miedos, desafíos de hombres y mujeres jóvenes: muertos y sobrevivientes. La multiplicación de los derrumbes íntimos, la clausura de alientos, de impulsos, de destinos.

El film aporta la visibilidad desconcertante de la resurrección del aliento en los relatos: se señalan los sitios, se ve a los asesinos abatirse sobre los heridos para terminar la tarea, se reconstruyen en la palabra los movimientos, los nombres y episodios de vida de compañeros caídos, se construye también otra visibilidad, la de la dignidad histórica de las luchas íntimas.

Esas imágenes iluminan la multiplicidad y el perfil enigmático de la memoria, sus facetas innumerables, sus tiempos y ritmos plásticos. Es la figuración de un silencio arraigado como testimonio de lo irrecuperable en la vida colectiva. Es la figuración tangible de una memoria indeleble que emerge, marcada todavía con el reclamo de olvido. Pero esas imágenes no son sólo pasado. Son también presente y prefiguración, vislumbre, la iluminación de una amenaza cumplida pero aún patente, irresuelta, siempre pendiente y tensa entreverada en la trama de los actos y de las alternativas de la acción colectiva.

\section{Imágenes testimoniales, poder y visibilidad}

La visibilidad contemporánea acoge ciertas imágenes inequívocas, otras imágenes inciertas, otras más enigmáticas. Sin embargo, hay imágenes cuya relevancia es en principio indiscernible, 
opaca, irreconocible. Éstas reclaman para su súbita inteligibilidad un trabajo de construcción que escapa a los recursos de la interpretación individual; involucran el contraste de la experiencia colectiva, la intervención de categorías analíticas surgidas de la experiencia misma de lo político, del develamiento instrumental de procesos cuya amplitud y complejidad desbordan el tiempo y la fugacidad de la mirada. Dos aperturas privilegiadas del cine político: sus imágenes sugieren, por una parte, la aprehensión "táctil", de la que hablara Benjamin, es decir, una comprensión inmediata de la densidad de la experiencia colectiva decantada en la imagen, librada a un saber emanado de la propia experiencia y de la colectiva y destinado a engendrar intimidad y vínculo. Es una aprehensión que se ofrece como síntesis y revelación de los silencios de la historia. Pero el cine político explora también otro recurso de la imagen: su capacidad de presentar una percepción insólita, intolerable, un paisaje del acontecer que requiere, más que la contemplación, una reconstrucción de la mirada como calidad del vínculo; la preservación de una tensión constitutiva del reconocimiento de lo otro, lo exorbitante, lo que reclama a un tiempo una respuesta y una alianza. Se erige desde una disección implacable y una meditación sin resguardos en la que la reflexión sobre la imagen es punto de referencia para la reflexión sobre sí y sobre el sentido de la acción recíproca y el vínculo ético. Responde a la lógica totalitaria de las estrategias de la visibilidad como espectáculo. La imagen como arma totalitaria, destinada a cancelar la fuerza política de la mirada. La atmósfera visual contemporánea ofrece la imagen como evidencia, como confirmación de los hábitos, como refrendo de las certezas y como consolidación y ahondamiento de los márgenes de incertidumbre y de repliegue sobre sí.

La imagen, troquelada en la lógica contemporánea de lo espectacular, no es en sí sino huella material de una figuración lumínica, efigie inerte, reiteración programada de estereotipos, 
estampa implantada en un soporte inerte, desprendida de la impronta de las sensaciones. Pero esa imagen conlleva un sentido trunco, esbozo de significación, cifra interrumpida, que su despliegue espectacular sofoca, cancela. Es un significado quebrantado, apenas una promesa tácita de sentido, de composición, de espera, que se extingue en la exaltación y la fuga. $\mathrm{Su}$ tiempo que cesa es la invocación abierta a una experiencia del tiempo como afirmación de la finitud: la imagen, había dicho Barthes, guarda una familiaridad con la muerte, con lo ya irreparablemente desaparecido. La imagen se inscribe siempre en un movimiento, insinuado y detenido - en el caso de la fotografía — o patente — en el caso de la imagen cinematográfica- o precipitado, imagen renuente a la demora de la meditación o del juego pulsional.

Pero la imagen reclama la distancia del ojo, supone la separación, la conformación de lo mirado como ajeno a la propia percepción natural, capaz de surgir en la experiencia como la prefiguración de la percepción de "otro". Es una distancia que no es sólo un alejamiento en el espacio, sino una extrañeza del sentido, una disyunción de horizontes, como incitación a la creación de vínculos y experiencias surgidos de esa misma extrañeza. Compromete una vacilación de las certezas, un vértigo de las interpretaciones. Es la plena revelación de la fertilidad política de la figuración, el rostro negativo, creador, del "terror de los signos inciertos", que había advertido alguna vez Roland Barthes. Un terror que surge de la capacidad de la imagen para quebrantar la fuerza de los hábitos, de los sentidos establecidos, del reposo de la responsabilidad. La mirada arrastrada por la incertidumbre de los signos se conjuga con las fantasmagorías, las efigies y los juegos corporales, los escenarios y los resplandores de la presencia, recobra su capacidad de creación y de invención de identidades.

No obstante, la imagen no puede eludir la gravitación de la trama narrativa, la fuerza articuladora de la composición cine- 
matográfica: testimonio, registro y ficción en un enlace íntimo. Pero en el vértice de la ficción del relato de la memoria, inherente a los tiempos del mirar, y en su precipitación en la sombra de los objetos, se dibuja la fuerza del vínculo con los otros. La capacidad de figuración política de las imágenes cinematográficas —o actualmente el video- hacen patente la condición limítrofe del testimonio. Dan lugar a una singular figuración de la historia construida con jirones destinados a la alusión, a la torsión alegórica de las presencias desplegadas en pantalla. La mirada cinematográfica asumida en su fuerza de implantación política es, de manera inherente, una intervención de la comprensión de la historia. Es la aprehensión figurada de los ritmos y la intensidad de devenir, como reinvención de lo atestiguado. Y, no obstante, la mera presencia de la mirada cinematográfica que exhibe en su simple "estar ahî" la voluntad de registro, es insoslayable: revela la violencia, la convoca, la intensifica, pero la capta en sus facetas más elusivas para inscribirla en la cauda de la experiencia colectiva.

Una convicción que anima los procesos políticos es el papel fundamental de la memoria en la lucha de emancipación, en la construcción de la autonomía política. Esta convicción se ampara en un gesto inequívoco de quienes someten a sus adversarios y pretenden su rendición sin condiciones o su aniquilación: el quebrantamiento de su identidad, la disolución de sus arraigos, la abolición de todos sus recursos simbólicos, la destrucción de todos sus patrones de identidad cultural, y la vacuidad de los sustentos de sus vínculos colectivos. El avasallamiento pasa por la aniquilación simbólica de los derrotados y su reducción a un silencio que va más allá de las palabras, hasta los propios cuerpos, alianzas, linajes, experiencias e historias. Quebrantar los núcleos de anclaje y recreación de las identidades, la visión de la violencia y las estrategias y condiciones del poder. Someter al otro a la aprehensión degradante de sí, a través de la experiencia de su propio desvalimiento. 
La dominación radical carece de límites: esa precipitación infinita culmina en su paradoja, la lucha de aniquilación. Es una lucha con dos desenlaces primordiales: o bien reclama la desaparición del otro, una desaparición no sólo corporal, sino radical, sin huellas, sin rastro, sin registro, sin nombre, sin siquiera un sedimento residual que aliente el testimonio; o bien el repudio y la exclusión absolutos, la disolución de todos los apuntalamientos psíquicos, afectivos, simbólicos que fundamentan la relación y la solidaridad entre los sujetos: el exterminio de sí que adviene con la disolución de lo social. Pero la realización de la aniquilación radical del otro es ajena a las estrategias modernas del poder, fundadas en la instauración de un riesgo y amenaza perennes. La aniquilación del otro, paradójicamente, extingue todo poder, cancela todo reconocimiento de la relación de servidumbre, toda visibilidad de la supremacía. No hay poder sin testimonio del desenlace de sometimiento inherente a las secuelas de la confrontación. La lucha de aniquilación debe entonces detenerse, construir una mirada testimonial, una "contemplación de la victoria", que consolide la memoria de su propia eficacia. Esta contemplación se transfigura y se incorpora en la experiencia como la preservación de un universo de amenaza, la exhibición de la extinción potencial del otro. Es la transfiguración de la amenaza en despliegue de violencia desbordada y paralizante, inicua, de destrucción de todo vestigio de alianza y la instauración del dolor como único recurso de la memoria.

La mirada testimonial surge como negación de esa "contemplación de la victoria", pero también como la ficción de las voces aniquiladas. No hay recuperación de lo radicalmente destruido. La fuerza del testimonio radica en la capacidad de la imagen para la aprehensión de la lógica de la aniquilación misma. El testimonio tiene ese imperativo oscuro que debe revocar: debe eludir el reconocimiento de la posición dominante de quien impone su fuerza y asumir el sometimiento y la ser- 
vidumbre del derrotado, y ponerse al margen de la ilusión ficticia de restaurar la devastación: el testimonio hace visible el acto mismo de la aniquilación, pone de relieve la insignificancia y la finitud históricas de toda dominación.

\section{Memoria y figuración cinematográfica}

La memoria inventa su propio tiempo, sus difusos paisajes y atmósferas, sus despliegues figurativos en permanente disipación y reconstitución, su disposición inextinguible al diálogo; la memoria no es la restauración de lo vivido, sino el rechazo de la mimesis del pasado. Supone el permanente desplazamiento narrativo en una composición alegórica al filo de la fantasía. La memoria elabora, a partir de esta potencia imaginativa los recursos de su propia certeza. La memoria, asumida como potencia de lo político, surge como una incesante construcción y reconstrucción de evidencias, una fusión y síntesis de reminiscencias, de lo vivido y de rastros disgregados de la experiencia en una permanente tensión disyuntiva contra los hábitos del lenguaje. Compromete la identidad de los esquematismos e inercias de los cuerpos, y la incorporación del sentido impersonal del régimen simbólico. La memoria participa de la invención de tiempo y de espacio que da forma y perfil a la intimidad, alienta la persistencia del deseo y la proyecta como una corroboración de la firmeza de lo vivido. Es la exigencia de una fundación incesante de los hábitos, la reconstitución de las certezas como continuidad ficticia de la identidad y como consistencia construida de lo vivido, como densidad y como saturación de la experiencia.

La memoria es el nombre de una multiplicidad inquietante e intrincada de procesos: proyección del deseo de futuro sobre el pasado, invención de un fundamento intemporal de la experiencia de lo finito y lo transitorio, disolución de tiempos y 
duraciones en virtud de las exigencias de lo vivido, composición del mundo en disposiciones autónomas, inflexiones de la palabra y conjugación de universos narrativos referidos a figuras, estampas y composiciones de actos que se desprenden del tiempo y se conjugan en frescos retrospectivos.

En uno de los trabajos fílmicos quizá más estremecedores de la historia del cine, experiencia cardinal del cine político y antecedente de la reflexión contemporánea sobre el Holocausto, Alain Resnais, en Nuit et brouillard, ${ }^{2}$ emprendió una experiencia radical de la memoria. Invención y preservación, esclarecimiento y crispación, grito y meditación, el film despliega las imágenes de los campos de concentración ya desiertos. Confinamientos inertes, patios y celdas exhibidos como paredes indiferentes. En composición paralela, las imágenes de la masacre, montañas de cuerpos inertes, lacerados, irreconocibles en su degradación inhumana. Imágenes cuya mera yuxtaposición es ya un estremecimiento: la estupefacción de la mirada y la exacerbación analítica y narrativa de la composición de imágenes y lenguaje. La visibilidad de lo atroz a través de sus vestigios indiferentes, sin huella, sin la atmósfera ceremonial del monumento. Los restos de los campos, las barracas vacías, semidestruidas, corroídas y ya cubiertas por la hierba - habían pasado apenas unos años del derrumbe final del nazismo- las cámaras de gas como claustros sombríos sembrados de signos agobiantes, pero sin la huella de los asesinatos innumerables. La secuencia de imágenes da un soporte visible a la comprensión de la abyección incalificable: ahonda en la atmósfera "banal" de las ruinas de la degradación.

La mirada neutra de la cámara registra las piedras, los restos metálicos, los recintos de la degradación, los hornos, las oficinas con la pulcritud del control administrativo de las desapariciones, en contraste con los miles de cadáveres sepultados

\footnotetext{
${ }^{2}$ Documental sobre el Holocausto y los campos de concentración nazis. Filmado en 1955. Dirección: Alain Resnais; Texto: Jean Cayrol.
} 
en fosas, arrastrados por maquinaria como la edificación de terraplenes y de tierra de la memoria, como la invención de otra fertilidad secreta. Es el paisaje de la materia inerte de un confinamiento inhabitable como mera prefiguración de lo indecible. Las imágenes de Resnais se fijan en las letrinas, las alambradas todavía en pie, aunque en jirones, los muros parcialmente derruidos, la corrosión de las láminas, los patios sin marca alguna de las represalias, los fusilamientos masivos, las torturas y las ejecuciones sumarias, la gravitación sin signos de los muertos: masivamente judíos, pero también comunistas, patriotas, gente equívoca, mujeres, hombres, niños, ancianos, la exigencia de totalidad y la vocación de absoluto del asesinato. Ante esas ruinas de apariencia inocua, el trayecto cinematográfico revela la derrota de la elocuencia de la mirada, extrema su vacío, la orilla al resguardo, al abandono, pero también al reconocimiento de lo absolutamente incalificable: los ojos - renuentes a lo intolerable - no pueden, sin embargo, apartarse de esas imágenes inocentes que se conjugan con la masa inadmisible de cadáveres en cuyas fisonomías, demacradas hasta confundirse con los huesos, se advierte la voluntad abyecta de degradación del aparato nazi y la respuesta intratable de la dignidad ante la voluntad de exterminio - figura limítrofe de la dignidad entendida como el resguardo sin reservas de lo humano que no puede ser sino la potencia del vínculo y la firmeza del aliento ético frente a los otros- La dignidad impregna esa mirada cinematográfica como perseverancia en lo otro de sí, en aquello que surge de la alianza con el proyecto humano en su fundamento primero.

\section{Secreto e intimidación: la visibilidad del terror}

La modernidad hace gala de una exacerbación de la visibilidad: la engendra y la despliega, la instrumenta como recurso 
constitutivo del ejercicio político, la resguarda como andamiaje operativo para las estrategias de poder. La visibilidad marca con su lógica la experiencia, nombra y significa los espacios, pone en relieve patrones de cuerpos, objetos y escenas para imponerlo como efigies normativas, hace patente el uso de la figura como soporte de las mecánicas institucionales. La visibilidad se modela según una economía puntual y una composición energética restringida, sobre cuerpos y sobre actos perfilados en sus impulsos originarios, en sus finalidades, en su sentido y sus valores.

Las estrategias de poder despliegan la visibilidad como una secuela trascendental del vasallaje, hacen del sometimiento una intemperie ineludible, encarnada; hacen tolerables los escenarios de la mortandad y la renuncia, las esperas doblegadas, los recodos en la militarización de la amenaza. Despliegan una economía del estigma y el desarraigo, acogen como una naturaleza la prescripción del mutismo, la invisibilidad del disenso, la visión confinada a las determinaciones de la violencia cotidiana. Es la escenificación espectacular de la violencia ofrecida como sustento de una amenaza tácita construida como estrategia anónima pero omnipresente de control de la experiencia. Las atmósferas de la amenaza se exhiben como una composición figurativa de la clandestinidad y el silencio, aunado al cinismo y la magnificación sublime de la ejecución de los crímenes. Exhibir como epopeya la planeación de las devastaciones y la diseminación de la desolación, la miseria y la matanza, la distribución del abatimiento político.

La modernidad ha inventado una visibilidad equívoca del asesinato de Estado. No bastan el exterminio ni la construcción de la "contemplación de la supremacía"; es preciso escenificar su celebración, instaurarla como un entorno sin tiempo, sustentar la invisibilidad de sus horizontes y sus fuentes, sepultar los vínculos en un resguardo anestésico, en un terror difuso e íntimo. El Estado escenifica no sólo la confiscación del 
ejercicio colectivo del control, sino la desmesura visible y el monopolio del uso del instrumental técnico y jurídico del asesinato, la asimetría incalculable de las armas, los ejércitos, las policías, frente a lo inerme de la acción colectiva. Vivimos ante el paisaje, cifrado en atmósferas de imagen, de la destrucción del Estado desplegada como espectáculo de la amenaza y como el ejercicio implacable de la devastación secreta de la vida. El poder surge a la luz imitando el movimiento inorgánico de la materia, como juego fatal de fuerzas, masas y resistencias. Aparece como despojado de sujeto, ofrecido como fuerza desmesurada de los elementos, como una lógica objetivada y autónoma, destinada a suscitar la contemplación de lo sublime. La modernidad suscita la convicción de la opresión inobjetable, como condición molecular de la "vida". La sobrevivencia individual deriva de la inteligibilidad de la acción posible sólo a partir de referencias a normas y formas simbólicas, cuyo sentido es amortiguar el estremecimiento de la violencia, instituida como preservación de la excepcionalidad.

Mucho más que detentar el poder de la violencia legítima, el Estado moderno - es decir, las estrategias conjugadas de los poderes multipolares, gubernamentales y no gubernamentales, y las formas de control instrumentadas por los gobiernos nacionales en los espacios moleculares de la vida colectivadetenta el ejercicio de la violencia ilegítima. No sólo ejercer la violencia "originaria" de la implantación de leyes y normas, o bien institucionalizar la otra violencia de su preservación, sino ejercer e instaurar como forma de vida la violencia suplementaria de la violación arbitraria de sus propias normas, de sus propias leyes, desbordar sus propias condiciones de preservación desde la lógica del poder excepcional. Esa arbitrariedad se ampara en su propia indeterminación: su inscripción en las fronteras de la visibilidad, de la ficción, de lo descriptible, el reconocimiento de las evidencias y su incorporación al dominio normativo; el manejo de la clandestinidad y su despliegue 
espectacular, la eficacia de la administración de su visibilidad, el control del secreto y las formas veladas del control, la escenificación del poder como evidencia de la potencia irrestricta de aniquilación. Esa violencia ilegítima, suplementaria, cancela toda alternativa de autonomía de los sujetos sociales, y funda ya no la ley ni su preservación sino una expresión de la fuerza pura de intimidación como norma tácita del desenlace de los conflictos. Erige la amenaza omnipresente como un régimen de la mirada y de la escucha, inherente a todos los órdenes de la experiencia. La delimitación de lo visible y la gestión de la presencia definen la suerte y el sentido de la palabra y la imagen testimoniales.

La figura contemporánea del "terrorismo de Estado" ha sido analizada por Chomsky a raíz de las políticas estadounidenses instrumentadas en los últimos 40 años, primero en el marco de la guerra fría, más tarde en el contexto de la guerra de Medio Oriente y recientemente con relación al atentado a las Torres Gemelas. El control por la vía de la tolerancia general del terrorismo de Estado se extiende asimismo a los demás países, entre ellos toda América Latina, en la tentativa de una ampliación sin restricciones de un control político unipolar de alcances globales e incidencia en lo íntimo.

La noción de terrorismo es ajena a la guerra misma. No es una de sus modalidades estratégicas. Es, incluso, su negación. El terrorismo es la transgresión de la guerra como régimen de confrontación. Es una forma de control destinada a la subordinación, la derrota o la aniquilación de un sujeto - colectivo o individual—, más allá de las reglas reconocibles de una confrontación entre entidades instrumentalmente reconocidasejércitos, contingentes expresamente destinados a asumir el riesgo de la muerte- $-y$, por consiguiente, regulada, en representación de las propias colectividades. El terrorismo no es una modalidad o un momento de la guerra. Es su reemplazo por el asesinato y la violencia de exterminio — ni siquiera de 
sometimiento o de control— ejercida más allá de las condiciones y los límites sociales que rigen la lucha como forma extrema de dirimir las catástrofes del intercambio o el desenlace tajante del poder. El terrorismo es un poder ejercido desde un más allá del poder, desde el territorio mismo de la abyección. Es un ejercicio de poder suplementario, exorbitante; es la exhibición de la desmesura del poder mismo que despliega su potencia de acción por encima de toda regulación, de toda acotación simbólica; es la exhibición de lo inhumano como rasgo de identidad de un sujeto por encima de todo sujeto, imponiendo su control arbitrario como la pretensión de una supremacía sin fronteras ni marcos: eso arbitrario puro se expresa en la realización impune y unilateral del asesinato a poblaciones o a sujetos ajenos a la dinámica de la destrucción.

Así, el único terrorismo real se da desde la posición real o simbólica del Estado, es decir, de un sujeto que se coloca a sí mismo más allá de todo vínculo, de toda responsabilidad, de toda ética, de toda política, de toda ley. Más aún, que, a través de la propia violencia ilegítima, se asume como origen, fundamento y garante de la ley. Hace de la ley misma el recurso fundamental del terror. Recurre al asesinato indiferenciado como invención de una supremacía ficticia y la afirmación de su propia potencia inconmensurable. El terrorismo sólo surge de una acción política capaz de instaurar por sí misma la ley que resguarda su propio ejercicio excepcional de la violencia de aniquilación. El actor se coloca a sí mismo en los umbrales de lo social, ajeno a la contingencia de sus actores y de la creación política, confiscando la capacidad de acción pública; es el Estado mismo. No hay terrorismo contra el Estado; ni siquiera podemos hablar de un "terrorismo de venganza", de la posibilidad de responder a un terrorismo de Estado con otro terrorismo individual, molecular. Al identificarse como origen de la ley, la acción terrorista, el asesinato de los inocentes, se coloca en la posición inherente a la fantasía y el delirio de Estado. 
Desde esa posición externa, reclama su capacidad de trastocar todos los ámbitos de la experiencia de todo sujeto. El terrorismo surge de la exacerbación de la operación ampliada hasta los ámbitos de la intimidad y del individuo, atribuyéndose como recurso primordial la posibilidad de la administración de la muerte y la desaparición de los otros y de sus vínculos.

El terrorismo apunta a engendrar el miedo, el desaliento, la disgregación de los vínculos y la desmoralización no en el ámbito de la guerra, sino en su materia social constitutiva: los lazos, los encuentros, las relaciones, las afecciones íntimas, las resonancias de la memoria y las redes simbólicas colectivas. Destruir al sujeto, sus vínculos y sus resguardos de identidad como instrumento para dirimir las confrontaciones de poder, establecer el sentido de supremacía como desenlace de la guerra. Así, la destrucción que la guerra misma no admite, se suscita desde ese más allá de ella para que el derrumbe del mundo social arrastre consigo al contrincante; que la aniquilación surja de la degradación y el hundimiento de la sociedad misma, cuando la guerra ha sido infructuosa, incierta o profundamente onerosa. Busca, por consiguiente, un efecto de poder y de control ejercido ya no en el marco del conflicto sino en su historia y su horizonte: apela a la diseminación y la intensificación de la angustia, capaz de desbordar las exigencias de todo intercambio y toda solidaridad social, la implantación de una atmósfera tácita de destrucción de lo social a partir de la proximidad y la inminencia de una muerte decretada al margen de todo imperativo, moral, ético, político o jurídico.

\section{La mirada de la bajeza: \\ la composición serial de las efigies del terrorismo}

Halcones es un ejercicio negativo de la visibilidad: más que hacer visible el efecto del poder, es revelar su mecánica y su 
instauración como forma de vida. Es una construcción de esa visibilidad como una emanación de la memoria: revela y devela las estrategias de esa instrumentación del terror y de su acontecer, de su irrupción intempestiva, de la escenificación de su arbitrariedad sin soporte, de su expresión en estrategias de visibilidad siempre desquiciantes. Es una detallada exploración de sus operaciones, sus cálculos, sus presupuestos de ataque, sus condiciones de eficacia, patentes en las imágenes, visibles en su lógica. Las descubre en su articulación analítica y las pone al descubierto en su escenificación. Vemos en esas imágenes el despliegue de estrategias estatales de diseminación del terror a través del reclutamiento y la alianza clandestina de los sectores devastados por la propia modernidad. Contingentes de jóvenes y hombres incorporados en una disciplina de asesinato mecánico, forjada y diseminada en los ejércitos de América Latina por la intervención estadounidense en la "institucionalización" del terror clandestino y el espionaje. Su operación supone el manejo ambiguo de las pautas ilegítimas de control social violento: exhibición de su desmesura y su eficacia, encubrimiento de sus estrategias y procedimientos.

En Halcones se mira nítidamente a los militares confundirse con los civiles o con la policía; se infiltran en posiciones estratégicas, en la implantación de disciplinas, en la conformación de las actitudes. El uso de la mimesis y de la escenificación de lo siniestro, como trastrocamiento de las identidades sociales, del extravío de la mirada arraigada en los vínculos. Es la disolución de los rasgos de reconocimiento de la diferencia, que fundan la expresión social de una ética y de una confrontación crítica entre acciones políticas disyuntivas. Doble mimesis: mimetismo al interior de sus propios contingentes, adoptan dócilmente la efigie de los modelos mercenarios que simulan la adopción de emociones patrióticas y el espíritu de cuerpo del ejército; pero también la estrategia de mimetismo exterior: el fingimiento, sembrar la confusión, vestir y gesticular, 
moverse como los que habrán de masacrar y gritar sus consignas, poblar los mismos territorios. Esa conjugación de mimesis y escenificación secreta requiere de un régimen compartido de claves secretas, la vigencia ciega de imperativos y fidelidades anónimas y sin anclaje en la sociedad, en la historia. Destinados al asesinato sin testigos ni testimonios, dispersos en la memoria sin otras huellas que la insistencia imborrable de estampas íntimas. La destrucción indeleble de los sobrevivientes.

El juego estratégico del terror radica en su diseminación, su capacidad de permear todos los ámbitos de la experiencia hasta volverlo imperceptible, cotidiano, tolerable: se transfigura en una mimesis de pérdida -integrar la destrucción de sí mismo, de su entorno, del otro como forma de vida- como universo capaz de abarcar todos los vínculos sociales, la intensificación de la angustia transformada en hábito, de sustentar la identidad colectiva en un miedo sin objeto, suscitado por los procesos íntimos de la pérdida. Es un terror encarnado, edificado como fantasma singular, convertido en territorio y memoria, en habitación y en expectativa.

La dinámica del terror es ávida, expansiva. Es extraña y hostil a todo lo que permanece más allá de sus alcances. Conlleva la aniquilación de todo aquello que circunda el momento y el impulso del terror: la invisibilidad de sus fuentes, la disolución de sus mecanismos y sus perfiles, el ocultamiento de todo cuanto lo revela y lo hace patente, lo que hace posible reconocerlo y que hace comprensibles sus secuelas. El terror tiene como horizonte el sacudimiento y la impregnación de la totalidad de lo social. El terrorismo es, intrínsecamente, el punto nodal de todo totalitarismo. La administración del terror y el dolor vivido o posible, inminente, induce al confinamiento en la esfera íntima, ahonda el solipsismo, exacerba hasta el delirio la búsqueda de la integridad y la preservación de sí. Toda presencia periférica al terror es en sí misma amenazante. 
Quien permanece ajeno a la amenaza, a la omnipotencia del terror, se pone al margen - $\mathrm{y}$ acaso por encima — de la supremacía de quien lo ejerce. Impone una supremacía de los fundamentos éticos, una persistencia del vínculo, una irreductibilidad de lo humano por encima de la inhumanidad del terror.

De ahí el terror como componente constitutivo de las estrategias modernas de exterminio, de supresión de lo social, de instauración del control molecular de las almas. Es el furor destructivo de quien impone el terror ante todo aquello que se ubica más allá de los límites del miedo irremisible, ante aquello que significa su impotencia, su fracaso.

La mirada fílmica de Halcones se conjuga con el impulso oral del relato de lo vivido, alienta una escritura audible, un archivo oral que se articula con las series de imágenes para alimentar la imaginación de lo político: sustenta la fuerza afirmativa del registro —es decir, la capacidad del registro para conjugarse con las imágenes, los recuerdos, los fantasmas y las certidumbres en la figuración analítica del pasado-, la edificación analítica de la memoria que formula una respuesta ética frente a la oscuridad de la violencia ilegítima. Esa potencia del registro en todas sus facetas expresivas conforma una composición de lógicas dispares que cancelan la violencia expansiva del régimen del terror.

Ubicarse más allá de los alcances del terror es afirmar la firmeza de un mundo ético inasequible a los pliegues exorbitantes del poder de Estado y de la racionalidad del control instrumentado en la modernidad. Es fincar en la experiencia política la fuerza de la ética como una faceta singular de la sobrevivencia: aquella que arraiga la vida en una contemplación que resiste al miedo, en la invención de una figuración simbólica del mundo y de los vínculos, al margen de la destrucción intrínseca de la amenaza y la primacía del asesinato. 


\section{REFERENCIAS}

BARTHES, Roland, 1964. "Rhétorique de l'image", Communications, 4, Paris, Seuil.

—, La chambre claire, 1981. Paris, Seuil-Gallimard-Cahiers du Cinéma.

Chomsкy, Noam, 2003. Pirates and Emperors, Old and New: International Terrorism in the Real World, Cambridge, South End Press. 